\title{
Introgression of semi-dwarf gene in Kalanamak rice using marker-assisted selection breeding
}

\author{
Deepti Srivastava $^{1,2, *}$, Md Shamim ${ }^{1,3}$, Anurag Mishra ${ }^{1,4}$, Prashant Yadav ${ }^{1,5}$, \\ Deepak Kumar ${ }^{1}$, Pramila Pandey ${ }^{1}$, Nawaz A. Khan ${ }^{1}$ and Kapildeo N. Singh ${ }^{1, *}$ \\ ${ }^{1}$ Department of Plant Molecular Biology and Genetic Engineering, N.D. University of Agriculture and Technology, Kumarganj, \\ Ayodhya 224 229, India \\ ${ }^{2}$ Integral Institute of Agricultural Science and Technology, Integral University, Lucknow 226021 , India \\ ${ }^{3}$ Dr Kalam Agricultural College, Bihar Agricultural University, Sabour, Bhagalpur 813 210, India \\ ${ }^{4}$ ICAR-Indian Agricultural Research Institute, New Delhi 110 012, India \\ ${ }^{5}$ Directorate of Rapeseed Mustard Research, Bharatpur 321 303, India
}

Kalanamak is an important aromatic rice variety in India. Tall stature of Kalanamak causes lodging due to which its yield and other characters severely declines. Introgression of the semi-dwarfing gene $\left(s d_{1}\right)$ from CSR10 was performed with the help of markerassisted breeding. Backcross-derived plants were characterized for semi-dwarf nature. Improved Kalanamak lines were analysed for the $s d_{1}$ gene and to check the presence of aroma, sensory analysis test and amplification with betaine aldehyde dehydrogenase 2 (badh 2) derived primer was performed. Improved versions of Kalanamak rice lines were either on par or superior in terms of yield, grain type and cooking quality with reduced height implicating the potentiality of marker-assisted backcross breeding for improvement of this rice variety.

Keywords: Aromatic rice, grain quality, lodging resistance, semi-dwarf gene.

AMONG scented rice, Kalanamak (kala = black husk; namak $=$ salt) is a non-basmati aromatic, small and mediumsized grain rice with strong and pleasant aroma. Presently, cultivation of this rice variety has been decreasing due to several biotic and abiotic stresses, including lodging. The tallness of plants is an important factor that causes susceptibility to lodging and ultimately causes a reduction in yield ${ }^{1}$. The semi-dwarfing gene in rice $\left(s d_{1}\right)$ is one of the most important genes deployed in modern rice breeding. Its recessive character results in a shortened culm with improved lodging resistance. The $s d_{1}$ gene has been cloned from rice and its dominant allele encodes gibberellin 20 oxidase-2 (GA20ox-2); a deletion or substitution mutation in this gene results in loss of its function. Thus plants showed deficiency of growth hormones,

\footnotetext{
*For correspondence. (e-mail: deeptifzd@gmail.com;

kapildeos@hotmail.com)
}

which control plant height ${ }^{2}$. PCR-based marker for $s d_{1}$ gene has been developed ${ }^{2}$. Varieties with $s d_{1}$ gene had better yields and lodging resistance ${ }^{3}$. Other dwarfing genes have also been used in the breeding programme, but many of them cause floret sterility, unusual plant and grain development ${ }^{4}$. Due to quality, aroma and palatability of Kalanamak rice, its price and demand in the global market are still high ${ }^{5}$. The candidate gene responsible for aroma, is badh2 ( $f g r)$, a recessive gene, located on chromosome 8 , encodes betaine aldehyde deydrogenase homologue 2 (BADH2). It is a key enzyme regulating 2-acetyl 1-pyrroline (2 AP) production ${ }^{6,7}$ and $2 \mathrm{AP}$ is mainly responsible for aroma in rice ${ }^{8,9}$ which is found in all plant parts of fragrant rice varieties, except the roots ${ }^{10}$.

Several methods are available to improve rice varieties, such as conventional breeding methods, molecular breeding, mutation breeding and transgenic approach. However, conventional breeding methods are time-consuming and influenced by the environment, while transgenic approach has biosafety issues in the present scenario. Molecular breeding involves the use of molecular markers that are economical, not influenced by the environment, accurate and requires less time. Several molecular breeding programmes in rice have been undertaken successfully for incorporation of semi-dwarf character without the loss of aroma ${ }^{11}$. Therefore, the present study was aimed at the introgression of $s d_{1}$ gene through marker-assisted selection breeding into the genetic background of Kalanamak rice, with its natural grain and cooking quality traits.

\section{Materials and methods}

\section{Plant material and breeding strategy}

Kalanamak rice was taken as the recurrent parent and CSR10 as the donor parent for the generation of $F_{1}$ plants. The $F_{1}$ plants were backcrossed with the 
Table 1. PCR primers used for marker-assisted selection in transferring semi-dwarf character in Kalanamak rice

\begin{tabular}{llc}
\hline Marker/primer pair & \multicolumn{1}{c}{ Primer sequence $\left(5^{\prime}-3^{\prime}\right)$} & Chromosome \\
\hline SD1 (semi-dwarfing) & F-CACGCACGGGTTCTTCCAGGTG & 1 \\
BADH2 (aroma) & R-AGGAGAATAGGAGATGGTTTACC & 2 \\
& F-TGCTCCTTTGTCATCACACC & 8 \\
\hline
\end{tabular}

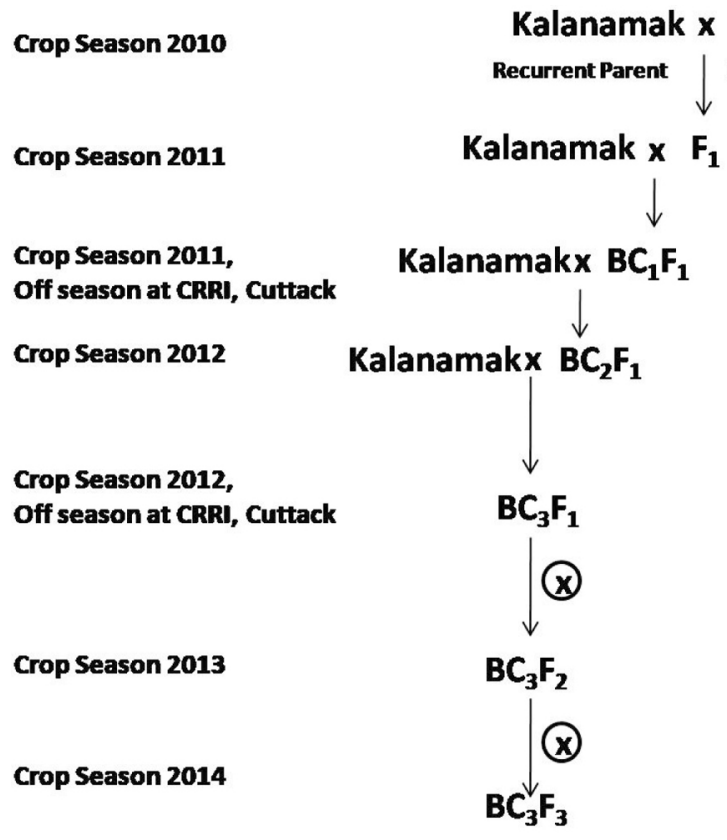

20 F plants were grown among which only 10 plants survived and hybridity test was done

$30 \mathrm{BC}_{1} \mathrm{~F}_{1}$ seeds developed and 15 plants were found positive after foreground selection

$70 \mathrm{BC}_{2} \mathrm{~F}_{1}$ seeds were grown among which 35 plants were found positive after foreground selection

$110 \mathrm{BC}_{3} \mathrm{~F}_{1}$ plants developed in which 55 plants were found positive after foreground selection and allowed for selfing

$200 \mathrm{BC}_{3} \mathrm{~F}_{2}$ plants grown among them only 12 plants were found positive after foreground selection and allowed the identified plants to self pollinate

$450 \mathrm{BC}_{3} \mathrm{~F}_{3}$ plants grown and phenotyped for plant height, aroma, cooking quality characters

Figure 1. Schematic diagram of introgression of dwarfing gene in Kalanamak rice from the donor CSR10 through markerassisted backcross breeding.

recurrent parent and positive $\mathrm{BC}_{1} \mathrm{~F}_{1}$ plants having $s d_{1}$ and badh2 genes were selected by PCR-based molecular markers (Table 1). Positive $\mathrm{BC}_{1} \mathrm{~F}_{1}$ plants were again backcrossed with the recurrent parent for the development of $\mathrm{BC}_{2} \mathrm{~F}_{1}$ generation and positive $\mathrm{BC}_{2} \mathrm{~F}_{1}$ was again backcrossed for the development of $\mathrm{BC}_{3} \mathrm{~F}_{1}$ generation. Selfing was carried out for the development of the $\mathrm{BC}_{3} \mathrm{~F}_{2}$ generation. Positive $\mathrm{BC}_{3} \mathrm{~F}_{2}$ plants were selfed to obtain $\mathrm{BC}_{3} \mathrm{~F}_{3}$ progenies (improved lines; Figure 1). Further, selected (semi-dwarf and aromatic) backcrossed progenies, along with recurrent parent Kalanamak, were evaluated in random block design (RBD). Thirty plants $(3 \times 10$ plants/per plot) were randomly selected for each tested line and scored for agronomic traits, viz. plant height $(\mathrm{cm})$, effective tillers/plant, panicle length $(\mathrm{cm})$, number of filled grains/panicle, spikelet fertility (\%), 1000 -grain weight (g), grain yield/plant and grain cooking quality traits.

\section{DNA isolation and molecular marker analysis}

Total genomic DNA from young leaves was isolated ${ }^{12}$ and checked on $0.8 \%$ agarose gel. PCR was performed in a
PTC-100 thermal cycler (BioRad, USA). For amplification with SD1 and BADH2 primer pairs (Table 1), PCR mixtures containing $50 \mathrm{ng}$ of template DNA, 5 pmol of each primer, $0.05 \mathrm{mM}$ of dNTPs (MBI, Fermentas, USA), 10× PCR buffer (10 mM Tris, $\mathrm{pH} 8.4,50 \mathrm{mM} \mathrm{KCl}, 1.8 \mathrm{mM}$ $\mathrm{MgCl}_{2}$ ) and $0.5 \mathrm{U}$ of Taq DNA polymerase (Merck India Pvt Ltd, New Delhi, India) in a reaction volume of $20 \mu \mathrm{l}$ were used. Template DNA was initially denatured at $94^{\circ} \mathrm{C}$ for $5 \mathrm{~min}$ followed by 35 cycles of PCR amplification with the following parameters: 1 min denaturation at $94^{\circ} \mathrm{C}, 1 \mathrm{~min}$ annealing at $55^{\circ} \mathrm{C}$ and $2 \mathrm{~min}$ of primer extension at $72^{\circ} \mathrm{C}$ followed by final extension of $72^{\circ} \mathrm{C}$ for $7 \mathrm{~min}$. The amplified products were electrophoretically resolved on a $4 \%$ agarose $\left(\right.$ MetaPhor $^{\mathrm{TM}}$ ) gel (Table 1 ).

\section{Sensory analysis test for aroma}

Aroma was tested by sniffing following a $\mathrm{KOH}$-based method $^{13}$. The sample was scored on a $0-3$ scale - score 0 for the absence of aroma, 1 for mild aroma, 2 for strong aroma and 3 for very strong aroma. Evaluation of aroma in the samples was carried out by an expert panel of five individuals.

CURRENT SCIENCE, VOL. 116, NO. 4, 25 FEBRUARY 2019 


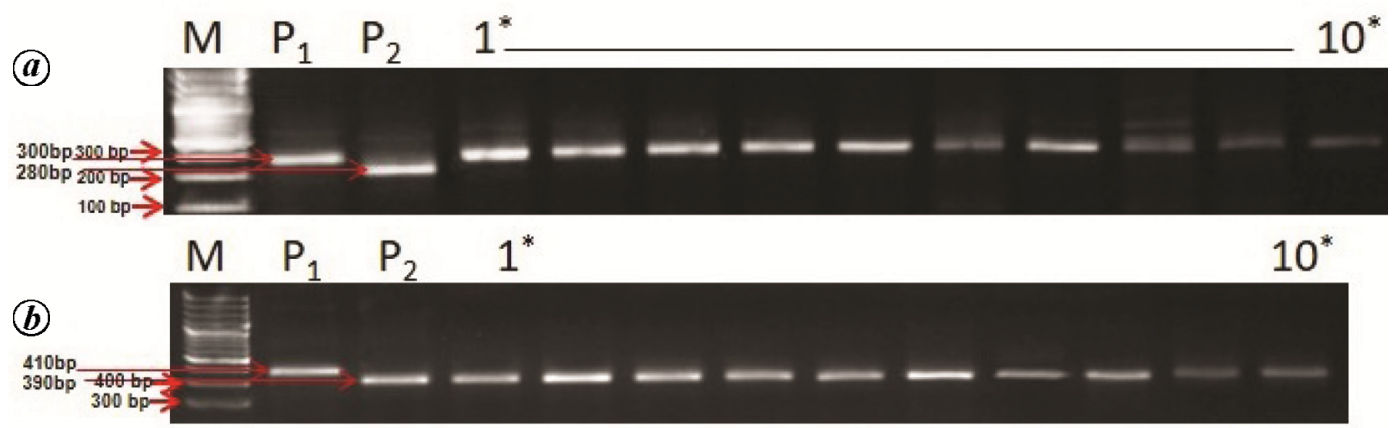

Figure 2. PCR analysis of the $s d_{1}$ gene with SD1 primer (a) and the badh2 gene with BADH2 primer (b) in parental lines (P1, CSR10 and P2, Kalanamak) and improved lines. Lane M, Molecular weight marker and lanes 1-10, Selected improved line individuals.

\section{Grain and cooking quality test}

The grains harvested from improved lines along with the parents (Kalanamak and CSR10) were analysed for physico-chemical characteristics like grain shape, dimensions of milled and cooked rice. For measuring the kernel length and breadth before and after cooking, three fully developed wholesome milled rice kernels were chosen and measurements made using a photo-enlarger.

\section{Statistical analysis}

Statistical analysis for agronomic traits, grain and cooking quality was done using Online Statistical Analysis Tool (OPSTAT) software: statistical version for agricultural work ${ }^{14}$.

\section{Results}

\section{Marker-assisted selection}

Marker-assisted selection was conducted on $F_{1}$ plants derived from the cross between Kalanamak and CSR10. Backcross generations developed by the crossing of positive $F_{1}$ with the recurrent parent were also tested for the $s d_{1}$ and badh2 genes. The amplified product with SD1 primer from the donor line was $300 \mathrm{bp}$ while in the recipient parent it was about $280 \mathrm{bp}$, which could be easily resolved on $4 \%$ agarose gel. Plants having both the bands in $\mathrm{BC}_{1} \mathrm{~F}_{1}$ (300 and $280 \mathrm{bp}$ ) were selected for further experiments (Figure $2 a$ ). The badh2 allele was amplified with 390 bp product size in Kalanamak and 410 bp product size in CSR10 (Figure $2 b$ ). Required alleles at the $s d_{1}$ and badh2 loci were determined in the next generation. Positive $\mathrm{BC}_{2} \mathrm{~F}_{1}$ plants were selected and backcrossed again for the generation of $\mathrm{BC}_{3} \mathrm{~F}_{1}$, which produced $200 \mathrm{BC}_{3} \mathrm{~F}_{2}$ individuals. Ten best semi-dwarf plants having aroma were identified from $\mathrm{BC}_{3} \mathrm{~F}_{2}$ generation and selfed to produce $\mathrm{BC}_{3} \mathrm{~F}_{3}$ generation (improved line). Improved lines were analysed for homozygous allele, agronomic performance, grain cooking quality and aroma. Only semi-dwarf improved plants were selected for agronomic and quality analysis. The genotyping results presented in Figure $2 a$ and $b$ are $\mathrm{BC}_{3} \mathrm{~F}_{3}$ improved lines having homozygous allele.

\section{Evaluation of agronomic performance in backcross lines}

Data on the agronomic performance of selected improved lines of Kalanamak $\times$ CSR10 with respect to traits like plant height $(\mathrm{cm})$, number of tillers, panicle length $(\mathrm{cm})$, spikelet/panicle, grain/panicle, spikelet fertility (\%), 1000-grain weight (g), and yield were recorded (Table 2). Plants having the $s d_{1}$ gene in backcross generation showed significantly reduced plant height (significant at $\mathrm{CD}=0.05$ ) in comparison to Kalanamak. A reduction of $17 \%-30 \%$ was observed in improved lines. Minimum plant height of $109 \mathrm{~cm}$ was observed in KC-4-7 (improved line). Improved lines produced more number of tillers with the higher number of spikelets and grain per plant (Table 2), and collectively contributed to the increase in grain yield/plant. A significant increase in the number of tillers/plant was observed in the line KC-4-10 producing up to 16 tillers in comparison of Kalanamak (11 tillers). Maximum number of spikelets/plant and grains/ plant was found in $\mathrm{KC}-4-7$ (227.66 and 210.00 respectively). However, maximum spikelet fertility percentage was found in line KC-4-4 (92.280). Improved lines of Kalanamak also had increased 1000 -grain weight in line KC-4-1 (22.66 g) in comparison to Kalanamak (12.66 g). The highest grain yield /plant was found in line KC-4-7 $(67.763 \mathrm{~g})$. Selected plants of improved lines showed better agronomic traits with shorter plant height and higher grain yield per plant (Figure $3 a$ and $b$ and Table 2).

\section{Grain and cooking quality of improved lines}

Improved lines also showed variation in husk colour. In Kalanamak, husk colour is black whereas CSR10 has a 


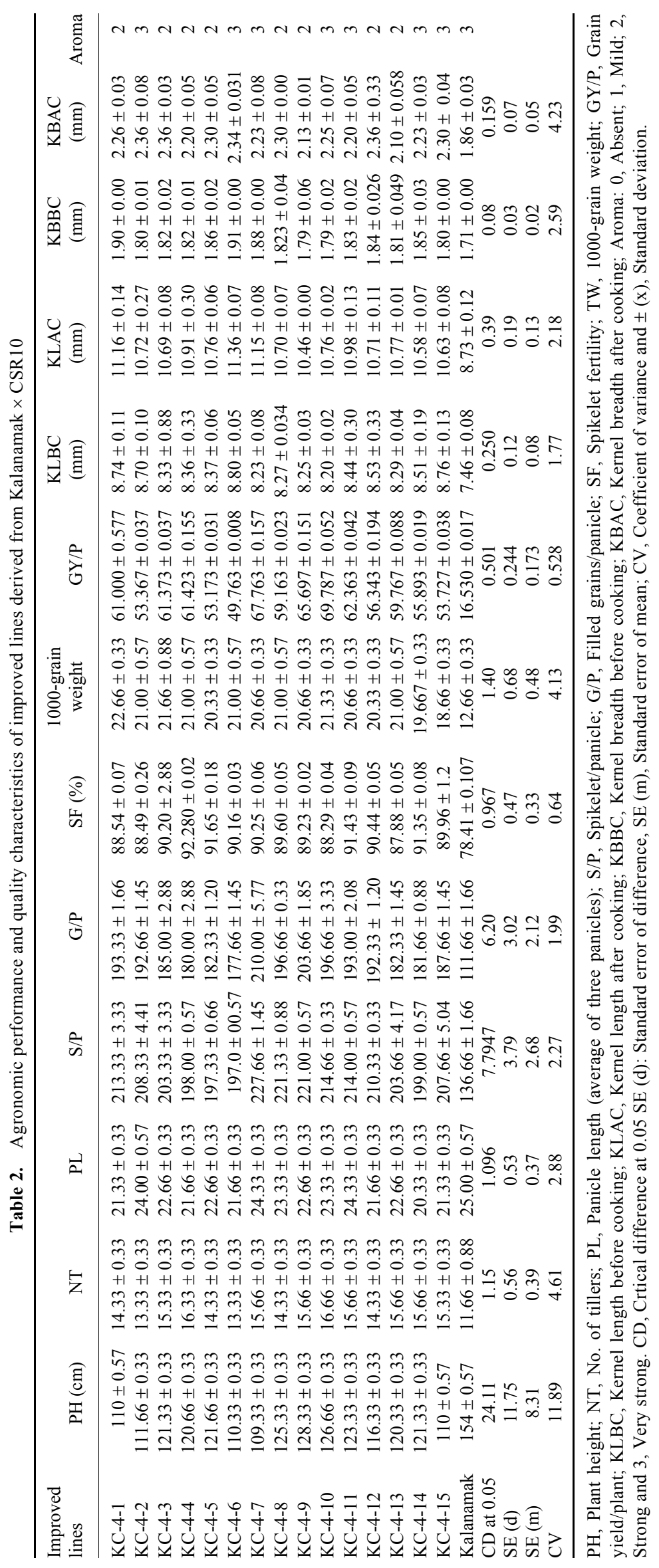




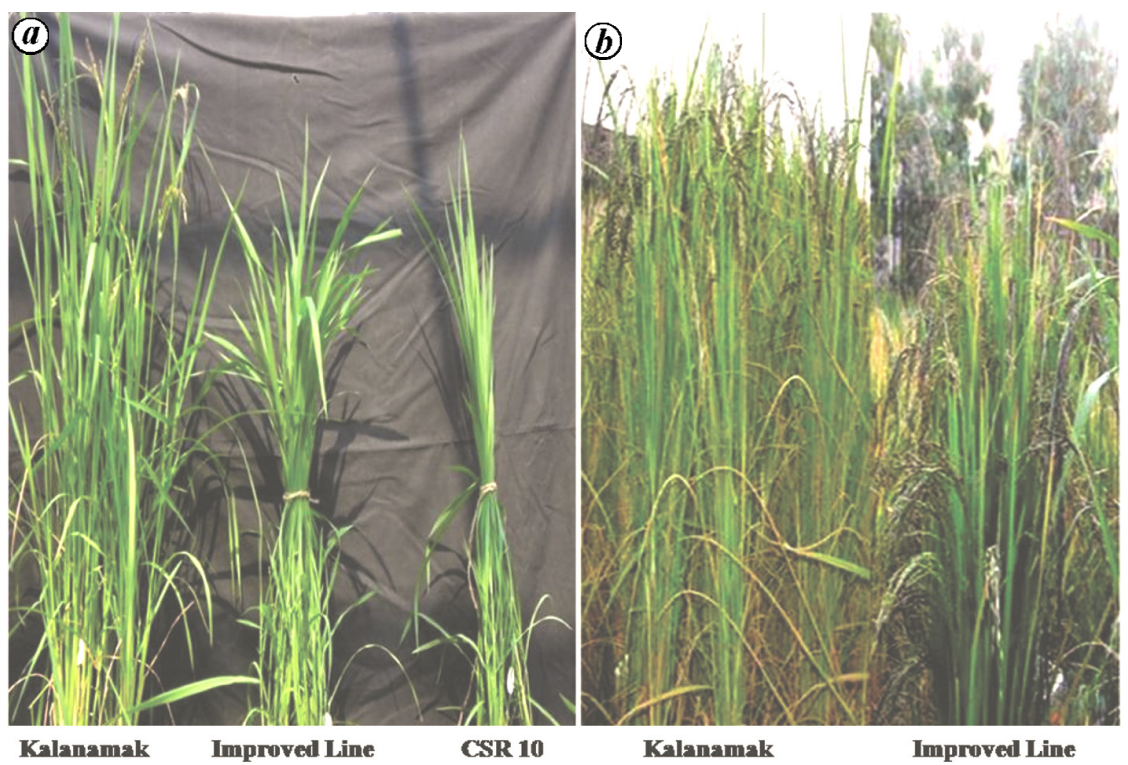

Figure 3. Morphological variation among the Kalanamak, CSR 10 and improved line at flowering (a) and between the Kalanamak and improved line at maturity stage (b).

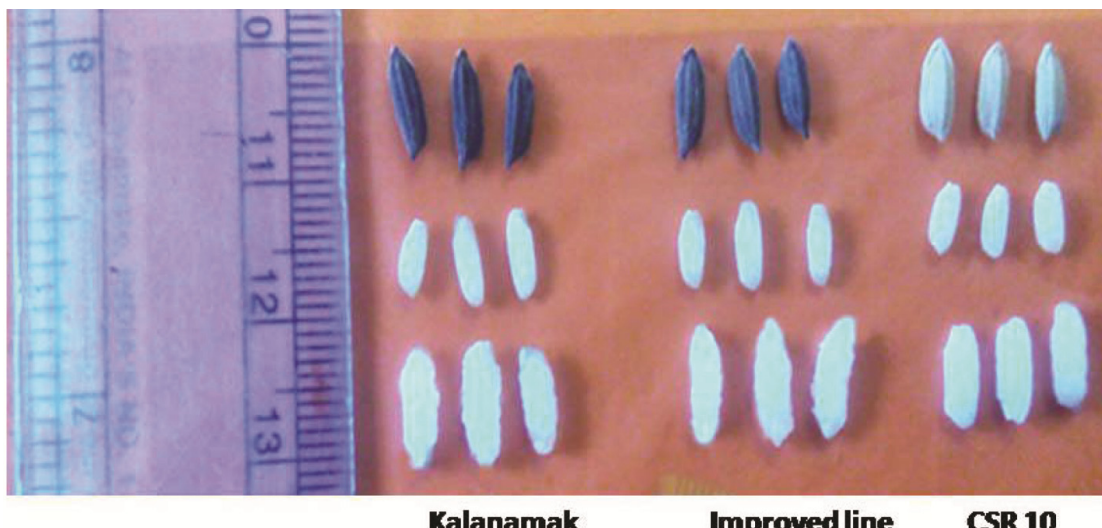

Figure 4. Variation in seed husk colour (top row), dehusked seeds (middle row) and cooked rice (bottom row) of improved line and parents (Kalanamak and CSR10).

yellow colour however, improved lines showed brown to black colour (Figure 4). Kernel length and breadth of improved lines also increased significantly (significant at $\mathrm{CD}=0.05)$ in comparison to Kalanamak rice. In line $\mathrm{KC}$ 4-5, kernel length and breadth (KLBC and KBBC) of rice grain before cooking was 8.80 and $1.91 \mathrm{~mm}$ respectively, while in Kalanamak, it was 7.46 and $1.71 \mathrm{~mm}$ respectively. Similarly, in line KC-4-1, kernel length and breadth (KLAC and KBAC) after cooking was 11.16 and $2.26 \mathrm{~mm}$ respectively, while in Kalanamak rice it was 8.73 and $1.86 \mathrm{~mm}$ respectively (Table 2 ).

\section{Aroma analysis by sensory test}

The polished and cooked kernels of Kalanamak, CSR10 and selected improved lines were analysed for aroma by the panel of five individuals, including a specialized biochemist (Table 2). Most of the backcrossed seeds scored
2 but some had a score of 3 , similar to Kalanamak, confirmed by the sensory test using milled rice seeds.

\section{Discussion}

Kalanamak, a non-basmati aromatic cultivar is one of the most prized rice varieties of Asia. Most of scented rice varieties have several undesirable traits such as lodging, low yield, vulnerability to pests and diseases ${ }^{15}$. These characteristics of Kalanamak rice reduce its agronomic value. The main reason for the reduction in yield of Kalanamak rice is its tall stature that causes lodging. The tall stature also limits optimum use of nitrogen fertilizer and causes problems in mechanical harvesting. Tall stature increases respiration, reduces translocation and causes chlorosis, which affect plant growth and development ${ }^{16}$. Semi-dwarf rice varieties can evade the damage caused by wind and rain due to their short height ${ }^{17}$. 
Therefore, there is a need to introgress semi-dwarfing gene into Kalanamak rice to overcome yield loss without losing its aromatic characteristics. In the present study, $s d_{1}$ gene from CSR10 was transferred in recurrent parent Kalanamak with the help of marker-assisted backcross breeding. Conventional breeding is more time-consuming and selection is based on phenotypic data, which require more number of plants ${ }^{17}$. Presently, marker-assisted selection (MAS) is based on the selection of plants with the help of molecular markers. These molecular markers reduce the selection cycle and are also precise and robust in nature. MAS selection requires screening of a small population size, thus ultimately reducing the time involved. Pyramiding of many target traits into the same cultivar is possible by MAS. There are many successful examples in the rice breeding programme, where MAS has been used for the improvement of agronomic traits as well as for disease resistance ${ }^{18-25}$, for semi-dwarfing traits $^{26}$. Basavaraj et al. ${ }^{27}$ successfully improved parental lines of hybrid Pusa RH10 with the help of markerassisted backcross breeding (MABB) using foreground selection and background selection. They reported that in two backcross generations, recurrent parent genome was recovered up to $97.30 \%$. Several studies in support of MABB such as biotic stress, abiotic stress and semidwarfing genes in rice have been successfully performed $^{28-33}$. Genetic basis of plant height in rice can be well understood by partitioning plant height into panicle length and length of upper internodes of rice ${ }^{34}$. In rice, molecular mapping of $s d_{1}$ gene has been reported ${ }^{35}$ which is located on chromosome 1. For the selection of backcross plants having semi-dwarf allele, SD1 primer pair was used ${ }^{2}$. Our results are consistent with previous study of $s d_{1}$ allele transfer ${ }^{36}$. In an earlier study, gene for aroma along with disease resistance and submergence tolerance has been also transferred ${ }^{37}$. Earlier $s d_{1}$ gene was used as semi-dwarfing character in rice through breeding programmes $^{38,39}$. Phenotyping for plant height was done at late developmental stage that reduce errors in the experiment for plant height observation ${ }^{2}$. Kovi et al. ${ }^{40}$ also developed backcross population by making crosses between Zhenshan 97 and Pokkali, for the transfer of semi-dwarfing gene where Zhenshan 97 was used as the recurrent parent. Rajpurohit et al. ${ }^{11}$ also pyramided three genes, two genes for bacterial blight resistance genes ( $x a 21$ and $x a 13$ ) and a semi-dwarfing gene $\left(s d_{1}\right)$ in type 3 Basmati from a rice cultivar PR106-P2 using MAS. In the present study, we successfully introduced $s d_{1}$ gene into the Kalanamak rice.

Aroma is a key trait in scented rice due to BADH (betaine aldehyde $)^{41-43}$. In rice, BADH has two homologs, $\mathrm{BADH} 1$ and $\mathrm{BADH} 2$, both having different expression patterns. While the expression of $\mathrm{BADH} 2$ is constitutive, that of $\mathrm{BADH} 1$ is not. $\mathrm{BADH} 2$ has the greatest affinity for 4-aminobutyraldehyde, which can spontaneously cyclize to form $\Delta 1$-pyrroline from which the fragrant compound 2-AP is formed in rice. Accumulation of $v$ guanidinobutyraldehyde (GGBald) results in the formation of 2-AP in fragrant rice ${ }^{41}$. In the present study aroma analysis in the introgressed line $\left(\mathrm{BC}_{3} \mathrm{~F}_{3}\right)$ was carried out by aroma (badh2) gene specific primer coupled with sensory analysis test. The $f g r$ gene is located on the long arm of chromosome 8 , and codes for the enzyme BADH, that also renders the badh2 gene product nonfunctional and leads to synthesis of 2-AP. Fragrance in rice appears to be due to the accumulation of 4-aminobutyraldehyde/ $\Delta 1$ pyrroline, which is a precursor of $2-\mathrm{AP}^{41}$. Aromaspecific, primer (badh2)-amplified 390 bp bands in $\mathrm{BC}_{3} \mathrm{~F}_{3}$ generation were selected for sensory analysis test and in most positive backcross generation, plant scoares were 2 and in some cases 3. The above results indicate the presence of badh gene, which is responsible for the expression of 2-AP and finally leads to fragrance in rice ${ }^{44}$.

\section{Conclusion}

In the present study we introgress the semi-dwarf gene $\left(s d_{1}\right)$ into the background of Kalanamak rice with the help of marker assisted breeding to minimize the losses due to lodging. The improved lines are short in height, either on par or superior in agronomic performance, grain and cooking quality traits compared to the recurrent parent Kalanamak rice. Further improved semi-dwarf Kalanamak rice variety will help farmers in reducing losses due to lodging. The improved lines will also be valuable as donors for semi-dwarfing gene for the pyramiding of semi-dwarfing character in aromatic rice breeding programmes.

1. Singh, R. K., Singh, U. S., Khush, G. S., Rohilla, R., Singh, J. P., Singh, G. and Shekhar, K. H., Small and medium grained aromatic rices of India. Aromatic Rice Science, Enfield Publishers Inc, USA, and Oxford and IBH Publishing Co, New Delhi, 2005, pp. 155-177.

2. Spiemeyer, W., Ellis, M. H. and Chandler, P. M., Semidwarf $(s d-1)$, 'green revolution' rice, contains a defective gibberellin 20oxidase gene. Proc. Natl. Acad., USA, 2002, 99, 9043-9048.

3. Lin, Y. R. et al., Mapping of quantitative trait loci for plant height and heading date in two inter-sub specific crosses of rice and comparison across Oryza genus. Bot. Stud., 2011, 52, 1-14.

4. Acquino, R. C. and Jennings, P. R. Inheritance and significance of dwarfism in indica rice variety. Crop Sci., 1966, 6, 551-554.

5. Luo, Y., Zakaria, S., Basyah, B., Ma, T., Li, Z., Yang, J. and Yin, Z., Marker-assisted breeding of Indonesia local rice variety Siputeh for semi-dwarf phenotype, good grain quality and disease resistance to bacterial blight. Rice, 2014, 7, 33.

6. Ahn, S. N., Bollich, C. N. and Tanksley, S. D., RFLP tagging of a gene for aroma in rice. Theor. Appl. Genet., 1992, 84, 825-828.

7. Cordeiro, G. M., Christopher, M. J., Henry, R. J. and Reinke, R. F., Identification of microsatellite markers for fragrance in rice by analysis of the rice genome sequence. Mol. Breed., 2002, 9, 245-20.

8. Bradbury, L. M. T., Fitzgerald, T. L., Henry, R. J., Jin, Q. and Waters, D. L. E., The gene for fragrance in rice. Plant Biotech. J., 2005, 3, 363-370.

9. Chen, S., Wu, J., Yang, Y., Shi, W. and Xu, M., The $f g r$ gene responsible for rice fragrance was restricted within $69 \mathrm{~kb}$. Plant Sci., 2006, 171, 505-514. 
10. Buttery, R. G., Ling, L. C., Juliano, B. O. and Turnbaugh, J. G., Cooked rice aroma and 2-acetyl-1-pyrroline. J. Agric. Food Chem., 1983, 31, 823-826.

11. Rajpurohit, D. et al., Pyramiding of two bacterial blight resistance and a semidwarfing gene in type 3 Basmati using marker-assisted selection. Euphytica, 2011, 178, 111-126.

12. Murray, M. G. and Thompson, W. F., Rapid isolation of high molecular weight plant DNA. Nucleic Acids Res., 1980, 8, 4321-4325.

13. Nagaraju, M., Mohanty, K. K., Chowdhury, D. and Gangadharan, C., A simple technique to detect scent in rice. Oryza, 1991, 28, 109-110.

14. Sheoran, O. P., Tonk, D. S., Kaushik, L. S., Hasija, R. C. and Pannu, R. S., Statistical software package for agricultural research workers. In Recent Advances in Information Theory, Statistics and Computer Applications (Hooda, D. S. and Hasija, R. C.), Department of Mathematics Statistics, CCS HAU, Hisar, 1998, pp. 139 143 .

15. Berner, D. K. and Hoff, B. J., Inheritance of scent in American long grain rice. Crop Sci., 1986, 26, 876-878.

16. Berry, P. M., Bradely, S., Pickett, R., Sterling, M., Baker, C. J. and Cameron, N., Lodging control through variety choice and management. In Proceedings of the Eighth HGCA R7D, Conference on Cereals and Oilseeds, Home Grown Cereals Authority, London, 2002, pp. 7.1-7.12.

17. Hirano, B. K., Ordonio, R. L. and Matsuoka, M., Engineering the lodging resistance mechanism of post-green revolution rice to meet future demands. Proc. Jap. Acad. Ser. B, 2017, 93, 220-233.

18. Katiyar, S., Verulkar, S., Chandel, G., Zhang, Y., Huang, B. and Bennet, J., Genetic analysis and pyramiding of two gall midge resistance genes (Gm2 and Gm6t) in rice (Oryza sativa L.). Euphytica, 2001, 122, 327-334.

19. Ramalingam, J., Basharat, H. S. and Zhang, G., STS and microsatellite marker-assisted selection for bacterial blight resistance and waxy genes in rice. Oryza sativa L. Euphytica, 2002, 127, 255-260.

20. Joseph, M., Gopalakrishnan, S., Sharma, R. K., Singh, V. P., Singh, A. K., Singh, N. K. and Mohapatra, T., Combining bacterial blight resistance and Basmati quality characteristics by phenotypic and molecular marker assisted selection in rice. Mol. Breed., 2004, 13, 377-387.

21. Zhang, J., Li, X., Jiang, G., Xu, Y. and He, Y. Q., Pyramiding of $X a 7$ and $X a 21$ for the improvement of disease resistance to bacterial blight in hybrid rice. Plant Breed., 2006, 125, 600-605.

22. Perumalsamy, S. et al., Functional marker-assisted selection for bacterial leaf blight resistance genes in rice (Oryza sativa L.). Plant Breed, 2009, 129, 400-406.

23. Gopala Krishnan, S. et al., Integrating marker assisted background analysis with foreground selection for identification of superior bacterial blight resistant recombinants in Basmati rice. Plant Breed., 2008, 127, 131-139.

24. Sundaram, R. M. et al., Introduction of bacterial blight resistance into Triguna, a high yielding, mid-early duration rice variety. Biotechnol. J., 2009, 4, 400-407.

25. Suh, J. P. et al., Development of elite breeding lines conferring Bph18 gene-derived resistance to brown plant hopper (BPH) by marker-assisted selection and genome-wide background analysis in japonica rice (Oryza sativa L.). Field Crop Res., 2011, 120, 215-222.

26. Lin, Y. R. et al., Mapping of quantitative trait loci for plant height and heading date in two inter-sub specific crosses of rice and comparison across Oryza genus. Bot. Stud., 2011, 52, 1-14.

27. Basavaraj, S. H. et al., Marker aided improvement of Pusa 6B, the maintainer parent of hybrid Pusa RH10, for resistance to bacterial blight. Ind. J. Genet. Plant Breed., 2009, 69, 10-16.

28. Basavaraj, S. H. et al., Marker-assisted improvement of bacterial blight resistance in parental lines of Pusa RH10, a superfine grain aromatic rice hybrid. Mol. Breed. 2010, 26, 293-305.

29. Perez, L. M., Redona, E. D., Mendioro, M. S., Vera Cruz, C. M. and Leung, H., Introgression of $\mathrm{Xa} 4, \mathrm{Xa}$ and $\mathrm{Xa21}$ for resistance to bacterial blight in thermosensitive genetic male sterile rice (Oryza sativa L.) for the development of two-line hybrids. Euphytica, 2009, 164, 627-636.

30. Zhou, Y. L. et al., Improvement of bacterial blight resistance of hybrid rice in China using the Xa23 gene derived from wild rice (Oryza rufipogon). Field Crop Res., 2011, 30, 637-644.

31. Hari, Y. et al., Marker-assisted improvement of a stable restorer line, KMR-3R and its derived hybrid KRH2 for bacterial blight resistance and grain quality. Plant Breed., 2011, 130, 608-616.

32. Nawarathna, R. N., Perera, A. L. T., Samarasinghe, W. L. G., Screening of BC1F1 population (BG 379-2/IR 07F102//BG 379-2) of rice (Oryza sativa L.) for submergence tolerance using molecular markers. J. Agric. Sci., 2014, 9, 154-156.

33. Yamamoto, T., Taguchi, S. F., Ukai, Y., Sasaki, T. and Yano, M., Mapping quantitative trait loci for days-to-heading, and culm, panicle internode lengths in a $\mathrm{BC}_{1} \mathrm{~F}_{3}$ population using an elite rice variety, Koshihikari, as the recurrent parent. Breed. Sci., 2001, 51, 671.

34. Maeda, H., Ishii, T., Takamure, I., Kinoshita, T. and Kamijima, O., Molecular mapping of semidwarfing gene, $s d-1$, using RAPD and RFLP markers. Breed. Sci., 1995, 45, 93-95 (in Japanese).

35. Neeraja, C. N., Vemireddy, L. R., Malathi, S., Siddiq, E. A., Identification of alternate dwarfing gene sources to widely used DeeGee-Woo-Gen allele of $s d-1$ gene by molecular and biochemical assays in rice (Oryza sativa L.). Electron. J. Biotech., 2009, 12, 111.

36. Luo, Y., Ma, T., Zhang, A., Ong, K. H., Li, Z., Yang, J. and Yin, Z., Marker-assisted breeding of Indonesia local rice variety Siputeh for semi-dwarf phenotype, good grain quality and disease resistance to bacterial blight. Rice, 2016, 9, 66.

37. Sasaki, A. et al., Green revolution: a mutant gibberellin-synthesis gene in rice. Nature, 2002, 416, 701-706.

38. Ashikari, M., Sasaki, A., Tanaka, M., Itoh, H. and Nishimura, A., Loss-of-function of a rice gibberellins biosynthetic gene, GA20 oxidase (GA20ox-2), led to the rice 'green revolution'. Breed. Sci., 2002, 52, 143-150.

39. Kovi, M. R., Zhang, Y., Yu, S., Yang, G., Yan, W. and Xing, Y., Candidacy of a chitin-inducible gibberellins responsive gene for a major locus affecting plant height in rice that is closely linked to green revolution gene sdl. Theor. Appl. Genet., 2011, 123, 705714.

40. Bradbury, L. M. T., Gillies, S. A., Brushett, D. J., Waters, D. L. E. and Henry, R. J., Inactivation of an aminoaldehyde dehydrogenase is responsible for fragrance in rice. Plant Mol. Biol., 2008, 68, 439-449.

41. Shi, W. W., Yang, Y., Chen, S. H. and Xu, M. L., Discovery of a new fragrance allele and the development of functional markers for the breeding of fragrant rice varieties. Mol. Breed., 2008, 22, 185-192.

42. Gaur, A., Shabir, W., Pandita, D., Bharti, N., Malav, A., Shikari, A. and Bhat, B., Understanding the fragrance in rice. J. Rice Res., 2016; http://dx.doi.org/10.4172/2375-4338.1000e125.

43. Wanchana, S., Kamolsukyunyong, W., Ruengphayak, S., Toojinda, T., Tragoonrung, S. and Vanavichit, A., A rapid construction of a physical contig across a $4.5 \mathrm{cM}$ region for rice grain aroma facilitates marker enrichment for positional cloning. Sci. Asia, 2005, 31, 299-306.

ACKNOWLEDGEMENTS. We thank the Department of Genetics and Plant Breeding, N.D. University of Agriculture and Technology, Kumarganj, Faizabad for providing of seed materials for this study, and the Director, ICAR-Central Rice Research Institute, Cuttack for conducting off-season trial.

Received 3 August 2018; accepted 15 November 2018

doi: $10.18520 / \mathrm{cs} / \mathrm{v} 116 / \mathrm{i} 4 / 597-603$ 